\title{
Novel Single Nucleotide Polymorphisms of Lysozyme (C-Type) Gene in Donkey (Equus Asinus) Populations in Marmara Province of Turkey
}

\author{
Raziye Işık ${ }^{1, a, *}$ \\ ${ }^{I}$ Department of Agricultural Biotechnology, Faculty of Agriculture, Tekirdağ Namık Kemal University, 59030 Tekirdăg, Turkey
} *Corresponding author

\begin{tabular}{|c|c|}
\hline A R T I C LE I NFO & A B S T R A C T \\
\hline $\begin{array}{l}\text { Received : 27/11/2019 } \\
\text { Accepted : 23/12/2019 }\end{array}$ & $\begin{array}{l}\text { The major antimicrobial proteins in donkey milk are lysozyme, lactoferrin, lactoperoxidase and } \\
\text { immunoglobulins. Lysozyme has an important role in the host defense by way it inhibits the } \\
\text { pathogenic bacteria. The aim of this study is to investigate the } L y \text { sozyme }(L Y Z) \text { gene polymorphism } \\
\text { in } 82 \text { donkeys reared in Thrace region of Turkey. } 716 \text { bp long partial } 5 \text { ' UTR, exon } 1 \text {, intron } 1 \text {, exon } \\
2 \text { regions of } L Y Z \text { gene were amplified and PCR products were analyzed via DNA sequencing. Three } \\
\text { novel single nucleotide polymorphisms (SNPs) were identified as g. } 1782775 \mathrm{~A}>\mathrm{G} \text {, g.1782924A }>\mathrm{G} \\
\text { and g. } 1782960 \mathrm{~T}>\mathrm{C} \text { in the first intron of } L Y Z \text { gene. The partial DNA sequence of } L Y Z \text { gene in } \\
\text { donkeys was reported in the present study and sequences of } L Y Z \text { were entered to NCBI Genbank } \\
\text { database with the accession number: MK984689-MK984692. This SNP may have an effect on } \\
\text { immune system and milk traits in donkeys and additional studies are needed to confirm this } \\
\text { assumption for donkey breeding. }\end{array}$ \\
\hline
\end{tabular}

Donkey

DNA sequencing

Turkey

\section{Türkiye Marmara Bölgesi Eşek (Equus Asinus) Popülasyonlarında Lizozim (C- Tipi) Genindeki Yeni Tek Nükleotid Polimorfizmleri}

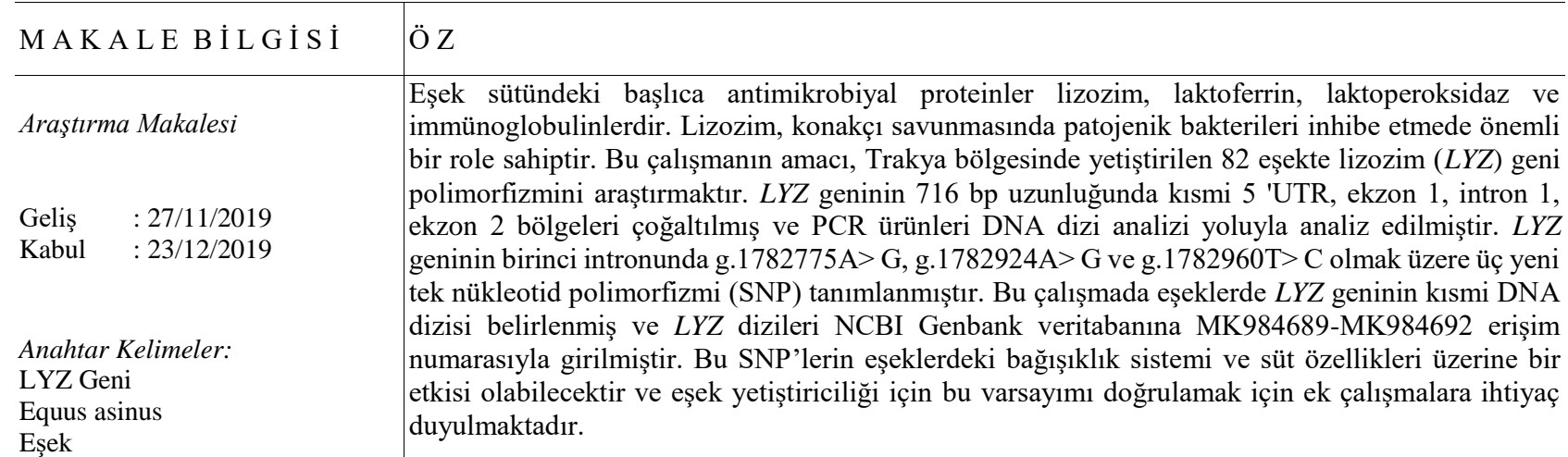

DNA sekanslama

Türkiye 


\section{Introduction}

Donkey milk has a great nutritional value and many functional features such as antimicrobial, antioxidant, antiviral, anti-inflammatory and hypoallergenic. These features are associated with lysozyme, immunoglobulins, lactoferrin, bioactive peptides, $\omega-3$ fatty acids of donkey milk (Tanaka, 2007; Tidona et al., 2011; Brumini et al., 2016; Stefaniuk-Szmukier et al., 2018). Thus, it has some differences from other ruminant milk such as fat ratio, minerals content, lactose and the presence of some antimicrobial proteins (Nayak et al., 2017). Donkey milk contains three main proteins; $\beta$-lactoglobulin $(\beta-\mathrm{Lg}), \alpha-$ lactalbumin ( $\alpha$-La) and lysozyme (Chiavari et al., 2005).

Lysozyme has an significant role in host defense by the way of hydrolyzing the polysaccharides via 1,4-betalinkages between $\mathrm{N}$-acetylmuramic acid and N-acetyl-Dglucosamine residues in peptidoglycan of bacterial cell walls. It inhibits the pathogenic bacteria and also it has a role as antimicrobial agent in milk (Palumbo et al., 2010). The lysozyme gene family contains three different genes and proteins such as lysozyme $c(L Y Z)$, lactalbumin which is also present in mammals and calcium-binding lysozyme which is also present in some birds and mammals (Irwin et al., 2011). Three different kinds of lysozymes have been determined such as chicken type (c-type), invertebrate type (i-type) and goose type (g-type). Equine milk lysozyme and ruminant lysozymes are taken part of the c-type family because of the resemblance with chicken egg white lysozyme. Equine lysozyme belongs to the family of c-type lysozymes, but has some structural characteristics typical to a-lactalbumins (Cosenza et al., 2017).

Lysozyme has an important role in reducing the gastrointestinal infections in the infants along with immunoglobulins, lactoferrin and lactoperoxidase. While donkey milk contains around $1 \mathrm{~g} / \mathrm{L}$ lysozyme c, bovine $(0.13 \mathrm{mg} / \mathrm{L})$ and human $(0.4 \mathrm{mg} / \mathrm{l})$ contain very low concentration of lysozyme $\mathrm{c}$ in milk (Stelwagen, 2003; Gubić et al., 2015). Donkey milk lysozyme molecular weight is approximately $14.9-15.4 \mathrm{kDa}$ (Gubić et al., 2015). $L Y Z$ gene is very conservative among the species such as bovine and goat $L Y Z$ gene have \%91 DNA sequence identity. $L Y Z$ gene is situated on chromosome 5 in goat-cattle, chromosome 6 in horse and on chromosome 3 in sheep. However, the location of $L Y Z$ gene is not clarified in donkeys. Also, it contains 4 exon counts in donkey, sheep, cattle and goat. The donkey lysozyme gene consists of 4 exons, 148 amino acids and 5193 bp long (NCBI, 2019).

Lysozyme c protein and gene sequences have been investigated from many vertebrate and non-vertebrate species (Irwin et al., 1996; Qasba and Kumar, 1997; Callewaert and Michiels 2010), but few data are available for donkeys (Cosenza et al., 2017; 2018). The aim of this study is to investigate the $L Y Z$ gene polymorphisms in donkeys via DNA sequencing method.

\section{Materials and Methods}

\section{Experimental Animals And Tissue Collection}

In the present study, a total of 82 blood samples were taken from Kirklareli (36), Tekirdağ (28) and İstanbul (Çatalca) (18) Provinces of Turkey. Blood sample were collected to $10 \mathrm{~mL}$ of vacuum tubes, including EDTA as anticoagulant and stored at $-2{ }^{\circ} \mathrm{C}$ till the DNA extraction. Genomic DNA was isolated by using a commercial DNA isolation kit (GeneJET Whole Blood Genomic DNA Purification Mini Kit, Thermo Fisher Scientific) according to the manufacturer's instructions.

\section{Primer Design, Total DNA Extraction and PCR}

Primer sequence of LYZ gene was designed based on the donkey sequence retrieved from GenBank (Accession number NW_014638180.1) using Primer-BLAST algorithm. Primer sequences of $L Y Z$ gene are F: 5'AGCTCTGCTGCAAGATGACA-3', and R: 5'GCTGAAGAAGGACACCTCCTC -3'. For amplification reactions, the $25 \mu \mathrm{L}$ PCR volume contained: $50 \mathrm{ng}$ genomic DNA, $0.5 \mu \mathrm{M}$ of each primer, $1 \times$ PCR Buffer $\left(\left(\mathrm{NH}_{4}\right)_{2} \mathrm{SO}_{4}\right), 200 \mu \mathrm{M}$ dNTP, $2.0 \mathrm{mM} \mathrm{MgCl}{ }_{2}$ and $0.5 \mathrm{U}$ of TaqDNA polymerase (Taq DNA Polymerase, Thermo Scientific, US). The cycling protocol was $5 \mathrm{~min}$ at $95^{\circ} \mathrm{C}$ for initial denaturation, 35 cycles of amplification; $94^{\circ} \mathrm{C}$ for 45 $\mathrm{s}, 60^{\circ} \mathrm{C}$ annealing for $45 \mathrm{~s}, 72^{\circ} \mathrm{C}$ for $45 \mathrm{~s}$ and $10 \mathrm{~min}$ at $72^{\circ} \mathrm{C}$ for final extension. The PCR products were checked on 1 $\%$ agarose gel using horizontal electrophoresis and the gels were stained using SafeView ${ }^{\mathrm{TM}}$ Classic (Applied Biological Material Inc. Canada).

716 bp of $L Y Z$ gene was sequenced by Applied Biosystems 3500XL Genetic Analyzer System (Applied Biosystems, USA) in order to identify the $L Y Z$ gene sequence. The electrophenograms were carefully checked by using ChromasPro Version 2.1.8 (Technelysium Pty. Ltd. Australia). The trimmed sequence file consisting of $L Y Z$ fragments were analyzed by the MEGA7 software (Molecular Evolutionary Genetics Analysis, version 6.0) (Kumar et al., 2016).

\section{Results and Discussions}

In this study we have identified the gene composition of $L Y Z$ gene in donkeys where LYZ was found in relation with immune system in farm animals. The genetic characterization of $L Y Z$ gene was analyzed by DNA sequencing and the matching with the DNA sequences taken from GenBank were conducted (Accession number NW_014638180.1). LYZ gene sequence is located between 1781536-1786728 bp at NCBI GenBank database records (Accession number NW_014638180.1). In our study, the studied $L Y Z$ gene region has spanned between $5^{\text {' UTR } 1^{\text {th }}}$ $-2^{\text {nd }}$ exon, partial $1^{\text {th }}$ intron and regions in donkeys and it includes 47 amino acids. It is shown the studied 716 bp long partial 3' UTR, exon 1 (yellow section), intron 1, exon 2 (blue section) regions and SNPs on the $L Y Z$ gene in Figure 1.

Three novel SNPs were identified as g.1782775A $>\mathrm{G}$, g. 1782924A $>\mathrm{G}$ and g. 1782960T $>\mathrm{C}$ in the first intron region of $L Y Z$ gene (Figure 2). These novel SNPs were identified and the partial DNA sequence of $L Y Z$ gene in donkeys was entered for the first time in this study and these sequences were enrolled to NCBI Genbank database with the accession number: MK984689-MK984692. 
gctgaagaaggacacctcctcagttacactctgcaacccttgacatactgagtgaggtcgcggttctgacaacgatttctccacgccaccc tgcagagaaaggtgaaaaaaatgggcataaggttaaaacgcatcttcactgtaatatgcatacttcacatccttggggagaacggaata gtttatcagtacacgcagcacgggctatggatggatccagctcgtgctgtttattacacggggatccatatcccaagtgcctctcttctcccc aaagccctcgctggagcacagaatgctggagcatagcatgttgggtgtgtgcatttccccagggcgactgccaagtgccttccacgtttac ctaattccaaaaataacttcaagacac $(\mathrm{A} / \mathrm{G})^{1782775}$ acaaggaactagtagagtgtggagaagcttacaactctagacaatccctaa aataaagtgagggtggagagtgggattccgaaccagttgaagtggattctttccagtgacaggctgtttgcgccaagtcgagagcctcag $\operatorname{tcttc}(\mathrm{A} / \mathrm{G})^{1782924}$ gctctcagccgcgtgctgtggtttctgaacttccc(C/T $)^{1782960}$ tcccacttctctcctaacagaaaggggaaaga gctttcccoctaatgctgagacgcaccatgctcggatgccctgtgggtcactgaccacccgctttgcacacgccacggettgagtgatgtc

\section{atcttgcagcagagct}

Figure 1. The studied 716 bp long partial 3' UTR, exon 1 (yellow section), intron 1, exon 2 (blue section) regions and SNPs on the $L Y Z$ gene

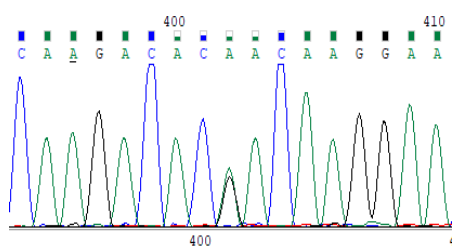

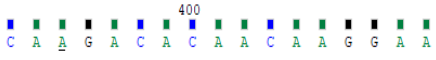

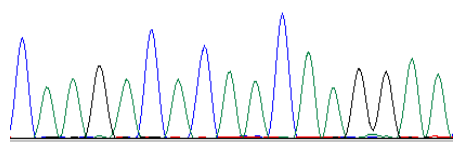

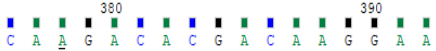

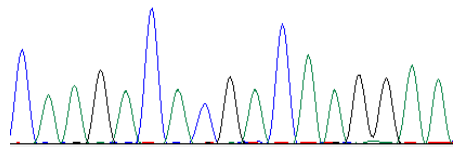

(a)
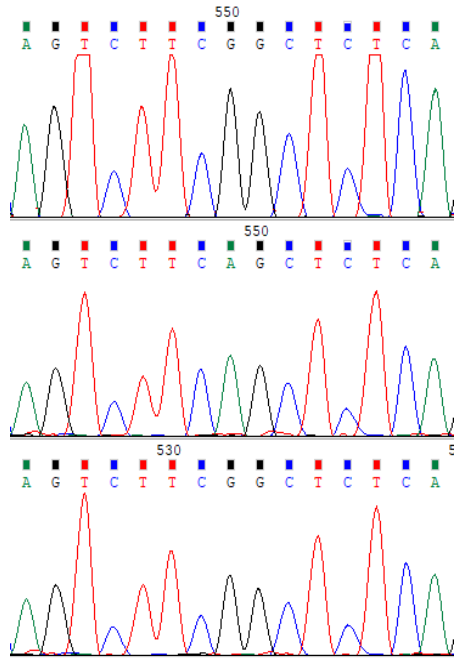

(b)

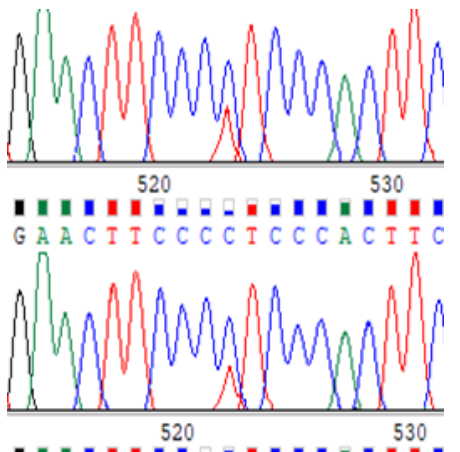

|| || || || || || || || || || || GAACITCCCCICCCACIIC

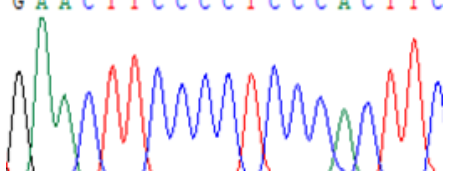

(c)

Figure 2. a) g. $1782775 \mathrm{~A}>\mathrm{G}$, b) g. $1782924 \mathrm{~A}>\mathrm{G}$ and c) g. $1782960 \mathrm{~T}>\mathrm{C}$ in the first intron region of $L Y Z$ gene

Cosenza et al. (2018) found two variants as A and B which differ at 32 positions and a SNP g.203C $>$ T that alters a putative binding site of the transcription factor NF-1 in the promoter region of $L Y Z$ gene. Cosenza et al. (2017) identified a transition $\mathrm{G}>\mathrm{A}$ at the $160^{\text {th }}$ nucleotide of exon 2 (NW_014638180:g-1784688C > T) caused an amino acid change from $\mathrm{Arg}^{90}$ to Gln. Šrić et al. (2012) analyzed the antibacterial properties of the lysozymes in raw donkey milk of Serbian breed. They found that the protective antimicrobial factors are very high in donkey milk which has positive effect on gut health and immune system. Nayak et al. (2017) clarified that lysozyme could be remarked as the notable antibacterial agent in donkey milk, because it is present in high concentration similar with Šarić et al. (2014). Aspri et al. (2018) reported that antimicrobial activity of donkey milk samples is high because it is digested with gastrointestinal enzymes similar as reported in Tidona et al. (2011). This antimicrobial effect in donkey milk might be partly because of high antimicrobial proteins as lactoferrin and lysozyme, the reason of this is predict as resistance to degradation by gastrointestinal enzymes.

Nayak et al. (2017) reported that lysozyme is an antimicrobial agent in donkey milk that effect gram positive bacteria, as well as a complex medium involving a large number of different compounds that may contribute to general antimicrobial potential.

\section{Conclusion}

Donkey milk has some differences from other ruminant milk with fat ratio, minerals content, lactose and the presence of antimicrobial proteins. The three crucial whey proteins in donkey milk are lysozyme, $\beta$-lactoglobulin and $\alpha$ lactalbumin. One of these antimicrobial proteins is lysozyme in donkey milk that is effective in the elimination of some viruses, anti-microbial activity, antitumor and inhibition.

Very few studies have been carried out on $L Y Z$ gene variations in donkeys. In this study, new polymorphisms are found which will implement beneficial information for improving food intake and immune response in donkeys based on marker-assisted selection. Thus, in further studies it is needed to perform more research and to realize the mechanism and pathways of lysozyme.

\section{References}

Aspri M, Leni G, Galaverna G, Papademas P. 2018. Bioactive properties of fermented donkey milk, before and after in vitro simulated gastrointestinal digestion. Food Chem., 268: 476484. https://doi.org/10.1016/j.foodchem.2018.06.119

Brumini D, Criscione A, Bordonaro S, Vegarud GE, Marletta D. 2016. Whey proteins and their antimicrobial properties in donkey milk: A brief review. Dairy Sci. \& Technol., 96(1): 1-14. https://doi.org/10.1007/s13594-015-0246-1

Callewaert L, Michiels CW. 2010. Lysozymes in the animal kingdom. J Biosci., 35: 127-160. https://doi.org/10.1007 /s12038-010-0015-5 
Chiavari C, Coloretti F, Nanni M, Sorrentino E, Grazia L. 2005. Use of donkey's milk for a fermented beverage with Lactobacilli. Lait, 85: 481-490. https://doi.org/10.1051 /lait:2005031

Cosenza G, Auzino B, Ciampolini R, Gallo D, Iannaccone M, Caprarelli R, Pauciullo A. 2017. Genetic variability detected at the (c-type) milk lysozyme encoding gene in donkey. ITAL J ANIM SCI., (ASPA 22nd Congress Book of Abstracts) 16: (1) 47-48. https://doi.org/10.1080/1828051X.2017.1330232

Cosenza G, Ciampolini R, Iannaccone M, Gallo D, Auzino B, Pauciullo A. 2018. Sequence variation and detection of a functional promoter polymorphism in the lysozyme c-type gene from Ragusano and Grigio Siciliano donkeys. Anim Genet., 49: 270-271. https://doi.org/10.1111/age.12647

Gubić J, Milovanović I, Iličić M, Tomić J, Torbica A, Šarić LJ, Ilić N. 2015. Comparison of the protein and fatty acid fraction of Balkan donkey and human milk. Mljekarstvo., 65(3): 168176. https://doi.org/10.15567/mljekarstvo.2015.0303

Irwin DM, Biegel JM, Stewart CB. 2011. Evolution of the mammalian lysozyme gene family. BMC Evol Biol., 11: 166. https://doi.org/10.1186/1471-2148-11-166

Irwin DM, Yu M, Wen Y. 1996. Isolation and characterization of vertebrate lysozyme genes, In Lysozymes: model enzymes in biochemistry and molecular biology. In: Jollès $P$, editor. Basel; Birkhäuser Verlag, pp. 225-241.

Kumar S, Stecher GM, Tamura KN. 2016. MEGA7: Molecular Evolutionary Genetics Analysis Version 7.0 for Bigger Datasets. Mol. Biol. Evol., 33(7): 1870-1874. https://doi.org/10.1093/molbev/msw054

Nayak CM, Ramachandra CT, Nidoni U, Hiregoudar S, Naik N, Ram J. 2017. Composition, Characteristics, Nutritional value and Health Benefits of Donkey Milk-A Review. Dairy Science \& Technology, EDP sciences/Springer. https://hal.archives-ouvertes.fr/hal-01538532

NCBI 2019. The National Center for Biotechnology Information. https://www.ncbi.nlm.nih.gov/gene/106842203, last access: 5 June_2019.
Palumbo D, Iannaccone M, Porta A. 2010. Capparelli R. Experimental antibacterial therapy with puroindolines, lactoferrin and lysozyme in Listeria monocytogenes-infected mice. Microbes Infect., 12: 538-545. https://doi.org/ 10.1016/j.micinf.2010.03.010

Qasba PK, Kumar S. 1997. Molecular divergence of lysozymes and alphalactalbumin. Crit Rev Biochem Mol Biol., 32: 255306. https://doi.org/10.3109/10409239709082574

Stefaniuk-Szmukier M, Ropka-Molik K, Zagrajczuk A, Piórkowska K, Szmatoła T, Łuszczyński J, BugnoPoniewierska M. 2018. Genetic variability in equine GDF9 and BMP15 genes in Arabian and Thoroughbred mares. Ann Anim Sci., 18(1): 39-52. https://doi.org/10.1515/aoas-20170035

Stelwagen K. 2003. Milk protein. Encyclopedia of Dairy Sciences. In: Roginski H, Fuquay JW, Fox PF, editors. London: Academic Press, pp. 1835-1842.

Šarić L, Šarić B, Mandić A, Torbica A, Tomić J, Cvetković D, Okanović Đ. 2012. Antibacterial properties of Domestic Balkan donkeys' milk. Int Dairy J., 25: 142-146. https://doi.org/10.1016/j.idairyj.2012.03.007

Šarić L, Šarić B, Kravić S, Plavšić DV, Milovanović I, Gubić J, Nedeljković NM. 2014. Antibacterial activity of domestic Balkan donkey milk toward Listeria monocytogenes and Staphylococcus aureus. Food and Feed Res., 41(1): 47-54. https://doi.org/10.5937/FFR1401047S

Tanaka T. 2007. Antimicrobial activity of lactoferrin and lactoperoxidase in milk, Dietary proteins research trends. New York: Nova Science Publishers, pp. 101-115.

Tidona F, Sekse C, Criscione A, Jacobsen M, Bordonaro S, Marletta D, Vegarud GE. 2011. Antimicrobial effect of donkeys' milk digested in vitro with human gastrointestinal enzymes. Int Dairy J., 21(3): 158-165. https://doi.org/10.1016/j.idairyj.2010.10.008 